\title{
APPENDIX
}

\section{Case Study to Data File Matrix}

\begin{tabular}{|c|c|c|c|}
\hline \# & TITLE & DATA FILE DESCRIPTION & CATEGORY \\
\hline 1 & $\begin{array}{l}\text { A Summer Internship } \\
\text { Journal }\end{array}$ & $\begin{array}{l}\text { Patient-level inpatient discharge data, including } \\
\text { data dictionary, } 344 \text { lines of time stamp data, and } \\
\text { calculated discharge turnaround times. }\end{array}$ & $\begin{array}{l}\text { Process } \\
\text { Improvement }\end{array}$ \\
\hline 6 & $\begin{array}{l}\text { Emergency Department } \\
\text { Heroes }\end{array}$ & $\begin{array}{l}\text { Over } 8,500 \text { lines of emergency department patient } \\
\text { encounters with length of stay and Emergency } \\
\text { Severity Index acuity level designations for each } \\
\text { patient discharge. }\end{array}$ & $\begin{array}{l}\text { Process } \\
\text { Improvement }\end{array}$ \\
\hline 8 & $\begin{array}{l}\text { The Cowboy Doctor's } \\
\text { Patient Experience }\end{array}$ & $\begin{array}{l}\text { HCAHPS patient experience surveys with } 29 \\
\text { questions from } 80 \text { patients. Includes data dictionary. }\end{array}$ & $\begin{array}{l}\text { Patient } \\
\text { Experience }\end{array}$ \\
\hline 9 & $\begin{array}{l}\text { Patient Navigation at } \\
\text { the Orthopedic Clinic }\end{array}$ & $\begin{array}{l}\text { Publicly reported Outpatient and Ambulatory } \\
\text { Surgery CAHPS facility-level data for over 1,200 } \\
\text { ambulatory surgery centers ( } 655 \text { facilities with } \\
\text { "linear mean scores"). Includes instructions on how } \\
\text { to create Percent Rank in Excel. }\end{array}$ & $\begin{array}{l}\text { Patient } \\
\text { Experience }\end{array}$ \\
\hline 10 & $\begin{array}{l}\text { HCAHPS and the } \\
\text { Quiet-at-Night Measure }\end{array}$ & $\begin{array}{l}\text { Summary HCAHPS Measures for hospital with state } \\
\text { and national } 75 \text { percentile benchmarks. }\end{array}$ & $\begin{array}{l}\text { Patient } \\
\text { Experience }\end{array}$ \\
\hline 11 & $\begin{array}{l}\text { Discharge Phone Calls } \\
\text { (En Español) }\end{array}$ & $\begin{array}{l}\text { Score summary data for } 24 \text { months of HCAHPS } \\
\text { overall patient experience surveys for one hospital. } \\
\text { Includes total, average, upper control limit, and } \\
\text { lower control limit. Demonstrates creation of control } \\
\text { charts. }\end{array}$ & $\begin{array}{l}\text { Patient } \\
\text { Experience }\end{array}$ \\
\hline 13 & $\begin{array}{l}\text { Reducing Patient Falls: } \\
\text { The Sleuth Resident }\end{array}$ & $\begin{array}{l}\text { Summary data for } 24 \text { months of patient falls for } \\
\text { one hospital by unit. Also includes total falls and } \\
\text { averages for five hypothesized root causes (patient } \\
\text { age, bed age, acuity, RN years of experience, and } \\
\text { average census) for each of the } 15 \text { patient units. } \\
\text { Ideal data for creating scatterplots. }\end{array}$ & Patient Safety \\
\hline 14 & $\begin{array}{l}\text { Sustaining Hand } \\
\text { Hygiene }\end{array}$ & $\begin{array}{l}\text { Over } 4,600 \text { lines of hand hygiene compliance data } \\
\text { by location, staff member, and pass/fail. }\end{array}$ & Patient Safety \\
\hline
\end{tabular}

(continued) 


\begin{tabular}{|c|c|c|c|}
\hline \# & TITLE & DATA FILE DESCRIPTION & CATEGORY \\
\hline 17 & $\begin{array}{l}\text { CLIF's Medication } \\
\text { Errors }\end{array}$ & $\begin{array}{l}\text { Six months of reported medication errors, } \\
\text { including patient information, harm scale, actions, } \\
\text { contributing factors, medication, and detailed event } \\
\text { descriptions. }\end{array}$ & Patient Safety \\
\hline 18 & $\begin{array}{l}\text { A Mom's Story of } \\
\text { Sepsis }\end{array}$ & $\begin{array}{l}\text { Hour- } 1 \text { Sepsis Bundle summary chart for Current } \\
\text { State. Instructor's file includes full and summary } \\
\text { failure modes and effects analysis. }\end{array}$ & Patient Safety \\
\hline 19 & $\begin{array}{l}\text { Operating Room } \\
\text { Recovery }\end{array}$ & $\begin{array}{l}\text { Almost 5,000 lines of patient-level time stamp data } \\
\text { for surgeries with over } 30 \text { fields, including room } \\
\text { ready, patient-in, procedure start. Includes data } \\
\text { dictionary with detailed instructions for writing } \\
\text { Excel statements for analyzing potential operating } \\
\text { room utilization opportunities. Instructor's file } \\
\text { includes completed analysis with pivot tables and } \\
\text { utilization calculations. }\end{array}$ & $\begin{array}{l}\text { Performance } \\
\text { Improvement }\end{array}$ \\
\hline 20 & $\begin{array}{l}\text { Opioid Overdoses } \\
\text { in the Emergency } \\
\text { Department }\end{array}$ & $\begin{array}{l}\text { Sixteen quarters of emergency department } \\
\text { drug overdoses attributable to opioids that are } \\
\text { summarized by quarter and monthly average. Data } \\
\text { file compatible with time-based trend analysis. }\end{array}$ & $\begin{array}{l}\text { Performance } \\
\text { Improvement }\end{array}$ \\
\hline 22 & The Fulfillment Affair & $\begin{array}{l}\text { Almost } 400 \text { lines of patient-level claims data, } \\
\text { including dates of service, diagnoses, place of } \\
\text { service, provider type, and total dollar amount } \\
\text { paid. Also includes a summary table with patient } \\
\text { name and primary diagnosis for the } 20 \text { highest cost } \\
\text { patients. }\end{array}$ & $\begin{array}{l}\text { Performance } \\
\text { Improvement }\end{array}$ \\
\hline 23 & $\begin{array}{l}\text { Composite Quality } \\
\text { Score }\end{array}$ & $\begin{array}{l}\text { CMS Overall Hospital Star Ratings for } 49 \text { hospitals, } \\
\text { including the seven separate quality measure } \\
\text { categories and composite scores. }\end{array}$ & $\begin{array}{l}\text { Performance } \\
\text { Improvement }\end{array}$ \\
\hline 24 & $\begin{array}{l}\text { Both/And Thinking in } \\
\text { Readmission Prevention }\end{array}$ & $\begin{array}{l}\text { Inpatient readmission reason tracking sheet with } \\
\text { diagnoses, discharge location, and reason for } \\
\text { readmission. Includes } 49 \text { patient-level readmissions. }\end{array}$ & $\begin{array}{l}\text { Performance } \\
\text { Improvement }\end{array}$ \\
\hline
\end{tabular}

CMS, Centers for Medicare and Medicaid Services; HCAHPS, Hospital Consumer Assessment of Healthcare Providers and Systems. 